\title{
BULLETIN
}

OF THE

\author{
UNITED STATES
}

\section{GEOLOGICAL SURVEY}

\section{No. 21}

THE LIGNITES OF THE GREAT SIOUX RESERVATION-A REPORT ON THE REGION BETWEEN THE GRAND AND MOREAU RIVERS DAKOTA

WA SHINGTON

GOVERNMENT PRINTING OFFIOE

1885 


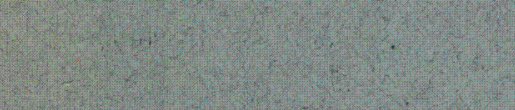




\title{
BULLETIN
}

\author{
OF THE
}

UNITED STATES

\section{GEOLOGICAL SURVEY}

No. 21

W A S H I N G TON

GOVERNALNT PRINTING OFFICE 

UNITED STATES GEOLOGICAL SURVEY

J. W. POWELI DIRFCTOR

\section{THE LIGNITES}

OF THE

\section{GREAT SIOUX RESERVATION}

BY

\section{BAILEY WILLIS}

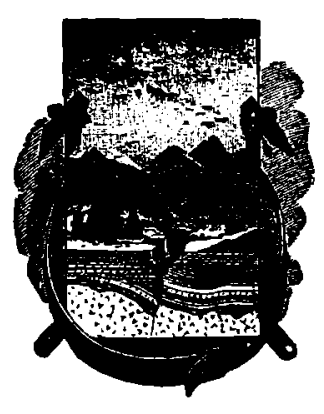

WA S H I NGTON

GOVERNMENT PRINTING OFFICE

1885 



\title{
IETTER OF TRANSMITTAL.
}

\author{
Department of the InTERior, \\ United States Geological Survey, \\ Washington, April 13, $188 \overline{\text { s. }}$
}

SIR: I have the honor to transmit herewith a report on the liguite beds of the Great Sioux Reservation, Dakota, the result of the survey ordered in your instructions to me under date of July 17, 1884.

Very respectfully,

BAILEY WILLIS, Geologist.

Hon. J. W. POWELL,

Director United States Geological Survcy. 



\section{CONTENTS.}

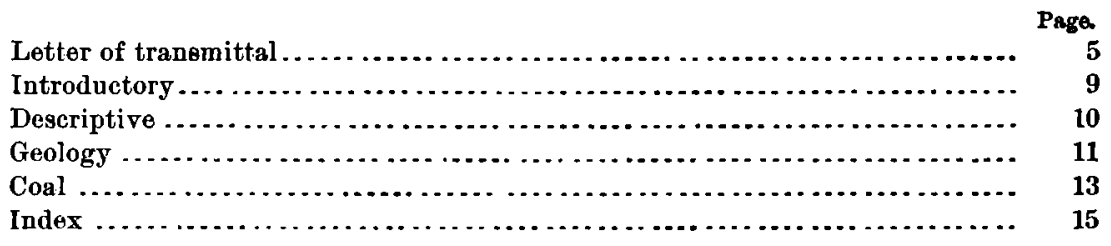

ILLUSTRATIONS.

Plate: I.-Sections of the Laramie-Rabbit Creek and Morenn River.

II.-Sections of tho Laramie-Flint Creek.

III.-Sections of the Laramic-Black Horse Creek and Grand River.

IV.-General map showing locality of survey.

V.-Topographic and geologic map of area surveyed.

Fug. 1.-Month of the Moreau River, looking north .................... 9

2.-Bluffs at the bead of Cotton wood Creeke ....................... 10

3.-Savdstone bluffs on Flint Creek ............................ 11

4.-Section of lignite bed ..................................... 12

(339) 7 



\title{
LIGNITES OF THE GREAT SIOUX RESERVATTON.
}

\author{
By BAILey Willis.
}

\section{INTRODUCTORY.}

Under the instructions of the Director of the United States Geological Survey, dated July 17, 1884, a party was organized and started from Mandan, Nakota, on July 24, to determine whether coal-beds of economic value exist within the Great Sioux Reservation, particularly near the Moreau River, and, if so, to define the limits of the coal-field. The party proceeded, by .way of Standing Rock Agency, to the mouth of the Moreau (Fig. 1), where it was detained five days by Cheyenne Indians. It then went westward over the high prairie within the bend to the north which the Moreau makes in approachiug the Mis-

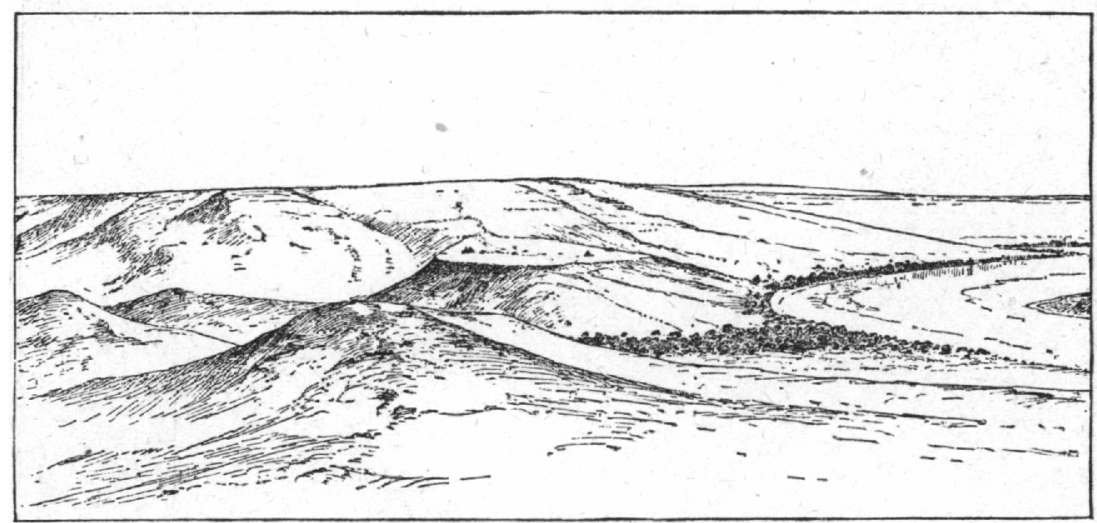

Fig. 1.-Mouth of the Morean, looking nor'b.

souri, crossed to the north bank $21 \frac{1}{2}$ miles west of the latter river, and ascended to the divide between the Moreau and Grand rivers.

Upon this long, narrow platean, 60 miles from the Missouri, the first beds of inferior lignite were found. With a greatest thickness of 2 feet 4 inches, these beds possess no commercial value; and, though the energies of the party were devoted to an examination of this formation for good fuel over an area of 2,000 square miles, the search was in rain. 
It may be definitely said there is no workable coal of any kind within the area surveyed; the fuel supply will he limited to the scattered groves of cottonwood along the principal streams for a period dependent on the growth of transportation facilities; and the scarcity of fuel and water will prevent close settlement for a long time.

\section{DESCRIPTIVE.}

The general easterly course of the rivers flowing through the Sioux Reservation to the Missouri defines the gentle slope of the plateau ly. ing east and northeast of the Black Hills ; at its eastern rim, along the Missouri, its elevation is about 400 feet abore the river, or 1,900 feet above the sea, and the ascent westward is barely perceptible.

Into this plateau the Cheyenne, Morean, Grand, and Cannon-ball Rivers have cnt tortuous, narrow valleys, 200 to 300 feet lower than the bluff's that bound them, and the small tributaries of these streams have slashed the bordering highland into an intricate radiating system of gulches and ridges. Between the waterways extend strips of rolling

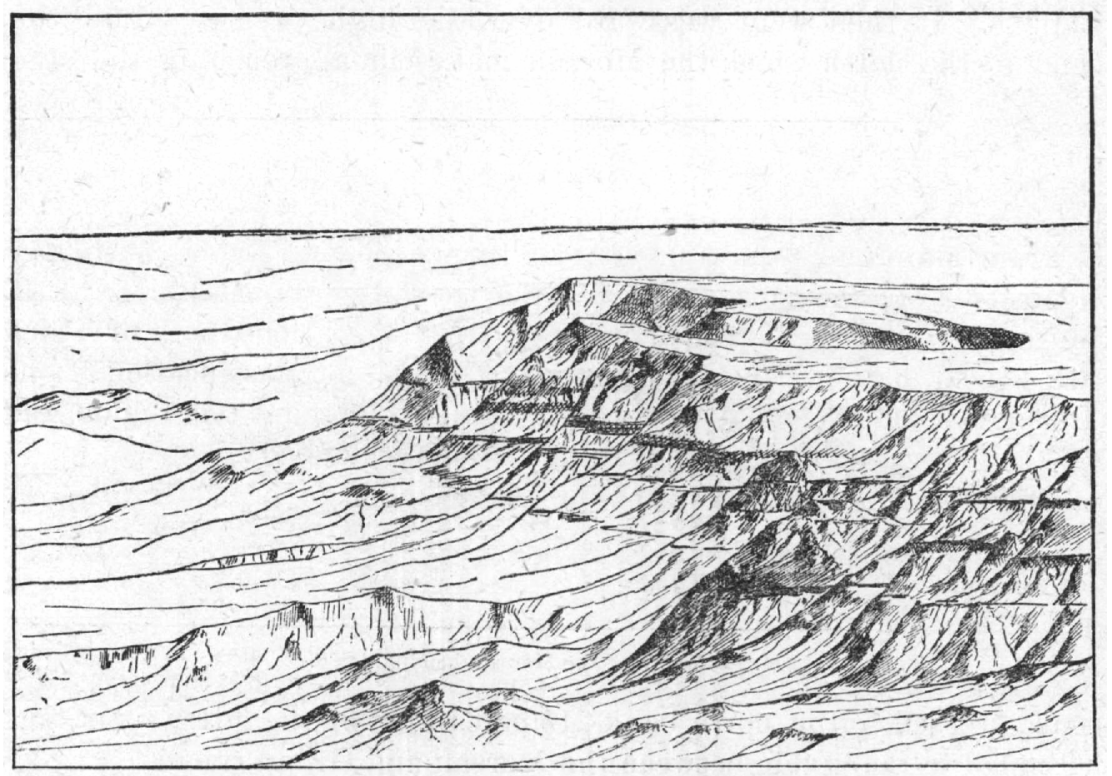

FIG. 2.-Bluffs at the head of Cottonwood Creek.

prairie, upon which stand isolated truncated or conical buttes 100 to 250 feet high, witnesses of the degradation suffered by the soft strata of the old plain.

Water flows sluggishly the year round in the larger tributaries of the 
rivers, such as Flint, Cottonwood, Black Horse, and Thunder creeks, and may be found in water-holes in many of the gulches throughout the summer. Those streams that have cut down into the dark "gumbo" clay of the Missouri bluffs are alkaline, while those which flow over the sandy beds of the Laramie are often only slightly so, or quite pleasant to the taste.

Within the area of the accompanying map the valleys of Cottonwood creek and of the Moreau slope directly south of it, are localities of greatest erosion, which partake of the bad land character, and their surface is scored with naked gullies (Fig. 2). The remaining greater portion of the region is grass-covered, and the "lay of the land" is favorable to stock-raising.

An interesting feature of the surface geology is the occurrence of erratic blocks of quartzite and granite on many of the elevations of the prairie. Some pieces of the quartzite contain silicified wood, which probably identifies it with the Dakota quartzites of the Black Hills, but more frequently the fragments are pierced with casts of stems from which the core has been removed. The surfaces of the blocks are highly polished by drifting sand, as was first shown by Dr. C. A. White, and the silicified wood has apparently been excavated from these casts by the same means, aided by alkali.

\section{GEOI,OGY.}

From Mandan to the Morean and thence west to Rabbit butte two deposits were recognized, which have been determined by Mr. J. B. Marcou to be of the Laramie and Fox Hills formations, both of which are placed in the Cretaceous group in the present classification of the Geological Survey. They are conformable throughout this region, and the boundary between them is often not easily defined.

The following table indicates the evidence of age :

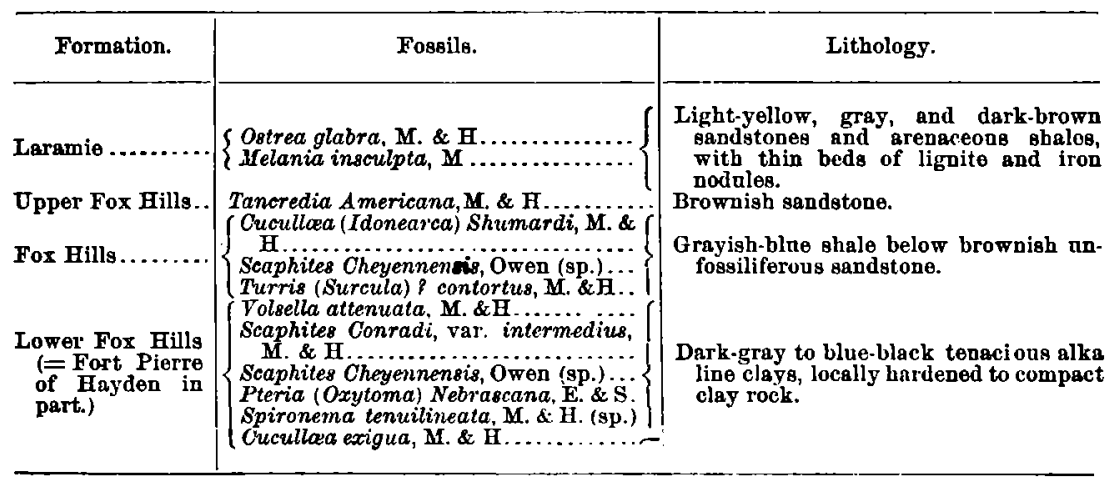


Rising from the Missouri over the dark clays of the lower formation ( which in lithologic character corresponds to the upper part of Hay. den's Fort Pierre, but is paleontologically identifiable with the Fox Hills), the Laramie first appears as a hard, gray, fine-grained sandstone, capping the isolated buttes on the plateau, which near the Mo. rean begin abont 35 miles west of the Missouri. The following sketch shows the effect of these caps on Flint Creek bluffs. (Fig. 3).

With the irregularity of character and thickness of the Laramie beds,

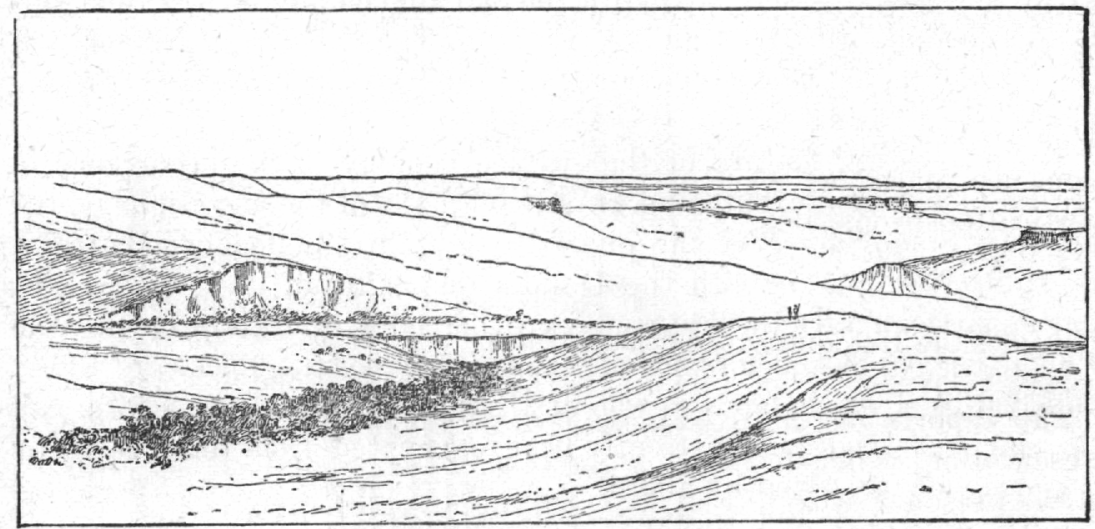

Fig. 3.-Sandstone bluffs on Flint Creek.

this sandstone grades over large areas into arenaceous shale or becomes soft and incoherent, and there is then much difficulty in determining its correct position.

The Laramie fossils were taken from accumulations of broken shells just above the horizon of this sandstone on Cottonwood and Thunder creeks, where they formed beds 6 to 15 feet thick and of several bundred feet lateral extent, evidently the wash of eddies.

The upper Fox Hills Tancredia was found in a brownish sand imme. diately below the gray Laramie sandstone at the lower crossing of Flint creek (see Plate II, Fig. 5); the Fox Hills fossils are from a gray shale immediately underlying a similar brownish sand-bed on the Moreau onehalf mile below the mouth of Thunder creek; while those assigned to the Fox Hills and Fort Pierre represent a horizon still lower in the blue clays in a locality on Grand River 15 miles east of Flint creek. Thus it appears that there is a gradual transition in this locality from the upper Fort Pierre clays through not more than 100 feet of Fox Hills beds to the lower sandstone of the Laramie.

The strata are practically horizontal over large areas, but sometimes show local dips of 10 to $3 \circ$. On the assumption that these local dips balance each other between the eastern limit of the Laramie on the Moreau and the top of Rabbit butte, the observed thickness of that formation is about 700 feet-probably less than half the original thickness over this area. 
The two thickest sections obserred are those illustrated in Figures 1 and 2 of Plate I, and Figures 5 and 6 of Plate III. The first is 348 feet, and the second 470 feet thick. If we could assume that the strata were absolutely horizontal from Black IIorse butte to Rabbit Creek, these two might be combined to form a section of 746 feet of the lower Laramie, which would inclucle thirteen lignite beds; but aside from the improbability of absolute horizontality of the beds over a distance of thirty odd miles, the section would have no representative value, as the beds of saudstone, slale, lignite, and irou ore pass into each other by abrupt changes of composition. This is illustrated in Plates II and III, where the sections are placed as nearly as possible in their relative vertical positious.

\section{COAL.}

The reports of the existence of coal in the Sioux Reservation, which led to this exploration, originated in the presence of lignite in sufficient quantity to furwish good specimens, and in the representations of Indiaus that they had found pieces of eastern coal, shown by them, on the reservation; which was true in so far as they found them at the agency blacksmith shops. There is no other coal than lignite on the reservation, and that is of poor quality. This result agrees with all observations of the Laramie coal-beds, which occur as typical lignites over thousands of square miles in the west, and are only altered to more condensed fuels in regions of intense local metamorphism.

The best exposure of lignite found is represented in Fig. 4. It crops ont in a little roll of the surface on one of the head branches of Flint creek. A careful section of a fresh cut gave: Roof (gray clay); earthy lignite, 3 inches; lignite, 2 feet 4 inches ; earthy lignite, 6 inches; foot-wall (gray clay).

Three hundred feet to the right of the section a bed of nodules of iron carbonate replaced the lignite. Four hundred feet off on the other side it had deteriorated to a brown clay. The other carbonaceous beds, ranging from brown shale to fair lignite, are shown in their proper relations ou Plates I, IJ, and III.

The manner in which these beds suddeuly end is shown

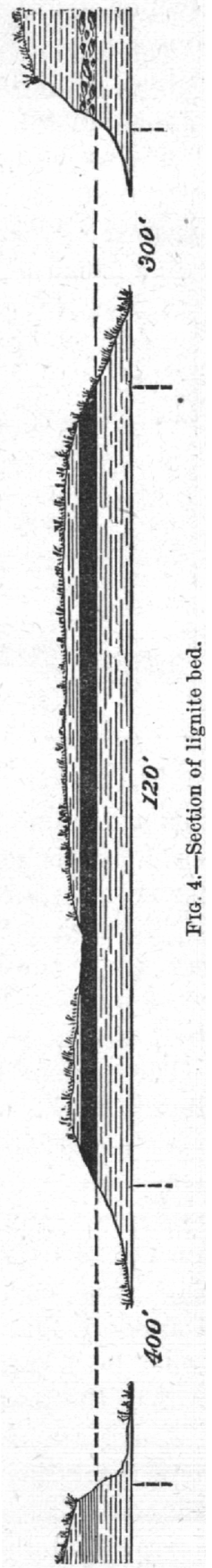
in one of the many cases observed in the lowest layer of Fig. 6, Plate III. 
As indicated in Fig. 4, lignites sometimes occupy the same horizon with nodular iron ores. The two have not been observed intermingled, though they might occur thus, and would then form blackband ore.

'The iron nodules are of gray carbonate of iron, oxidized on the outside to limonite, which often has a dark reddish tint indicating an approach to the composition of hematite. The shrinkage in volume of this oxidized layer cracks it into polygonal bits that adhere firmly to the unaltered core. In this respect these carbonates differ from those of the eastern coal measures, which alter into shells of limonite, readily separable from each other and from the core.

These ores are too far from fuel and limestone to have commercial value. 


\section{INDEX.}

Alkali

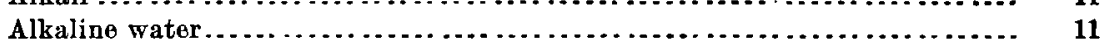

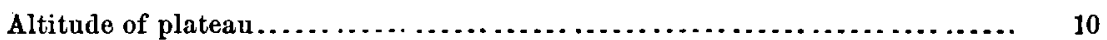

Black Hills . . . . . . . . . . . . . . . . . . . . . . . . . . . . . . . . . . . . . . 11

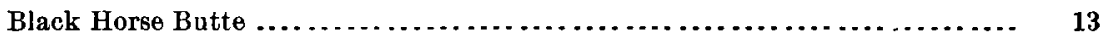

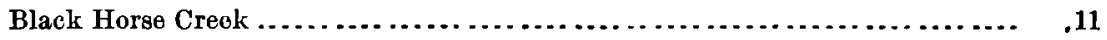

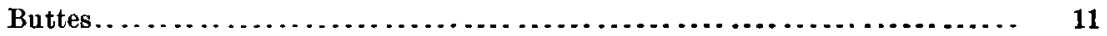

Cannonball River ............................................ 10

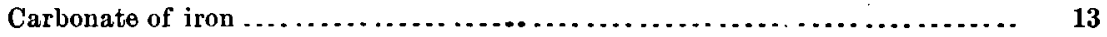

Cheyenne Indians. . . . . . . . . . . . . . . . . . . . . . . . . . . . . . . . . . . . 9

Cheyenne River........................................... 10

Coal. .................................................. 9,13

Conformity ......................................... 11

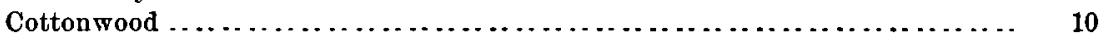

Cottonwood Creck .......................................... 11

Cretaceous ............................................. 11

Cucullca exigua............................................. 11

Cncullaa (Idonearca) Shumardi .................................... 11

Dakota quartzites. ... . . . . . . . . . . . . . . . . . . . . . . . . . . . . . . . . . 11

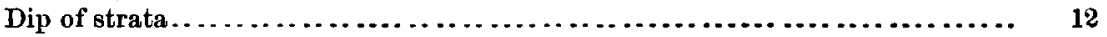

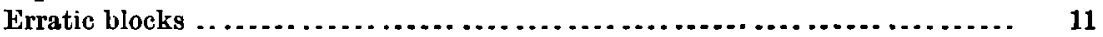

Flint Creek .................................................... 11, 12, 13

Flint Creek Bluffs . . . . . . . . . . . . . . . . . . . . . $\ldots \ldots \ldots \ldots \ldots \ldots \ldots \ldots \ldots \ldots \ldots$

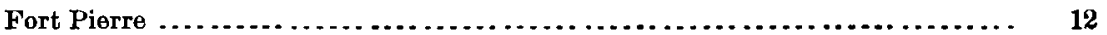

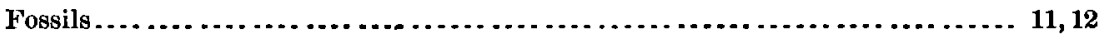

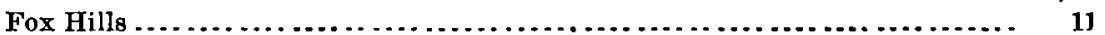

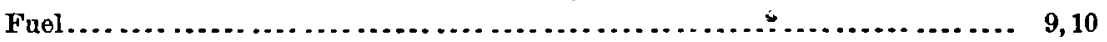

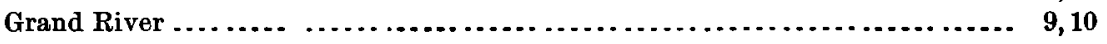

Great Sioux Reservation ....................................... 9

"Gumbo" clay, ................................................ 11

Hayden, F. V., cited ............................................ 12

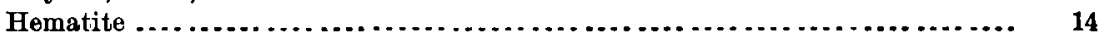

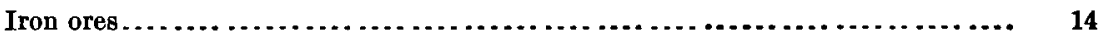

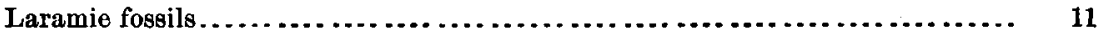

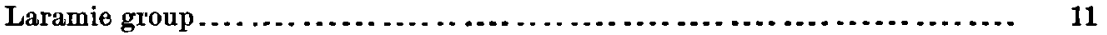

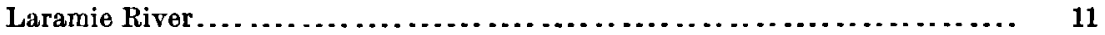

Letter of transmittal $\ldots \ldots \ldots \ldots \ldots \ldots \ldots \ldots \ldots \ldots \ldots \ldots \ldots \ldots \ldots \ldots \ldots \ldots \ldots \ldots \ldots \ldots \ldots . \ldots 5$

Lignite ..................................................... 9,13

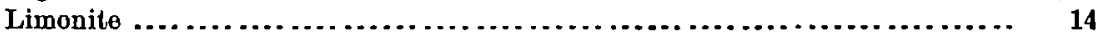

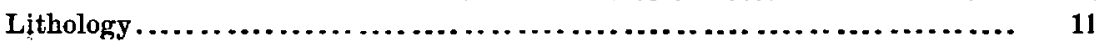

Mandan, Dakota .......................................... 9,11

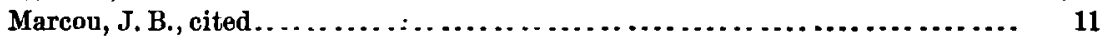

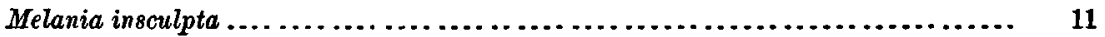

Missouri River .................................................9, 10, 12

Moreau River $\ldots . \ldots \ldots \ldots \ldots \ldots \ldots \ldots \ldots \ldots \ldots \ldots \ldots \ldots \ldots \ldots \ldots \ldots, \ldots \ldots \ldots \ldots \ldots \ldots . . . \ldots, 11$ 


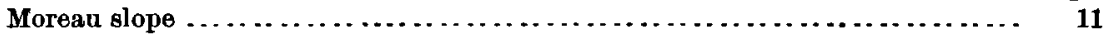

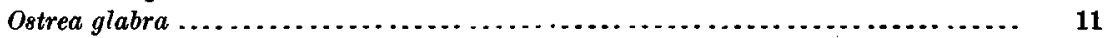

Pteria (oxytoma) Nebrascana.................................. 11

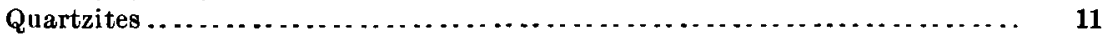

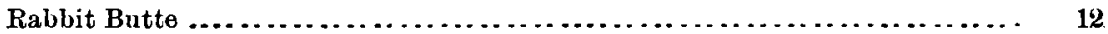

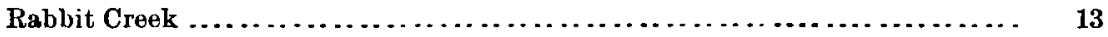

Suaphites Cheyennensis...................................... 11

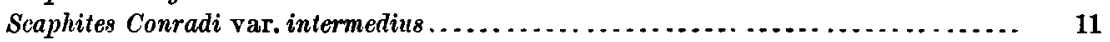

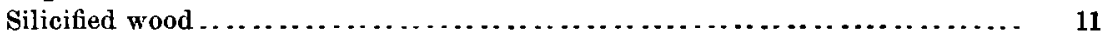

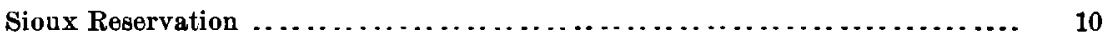

Spironema tenuilineata ....................................... 11

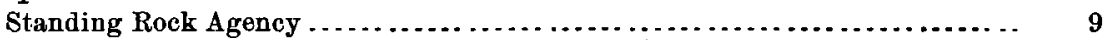

Tancredia Americana ......................................... 11

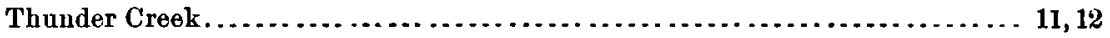

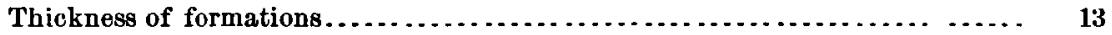

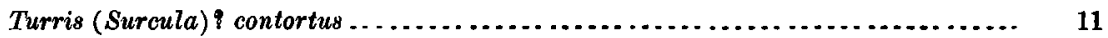

Upper Fox Hills . . . . . . . . . . . . . . . . . . . . . . . . . . . . . . . . . . . 11,12

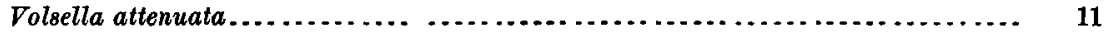

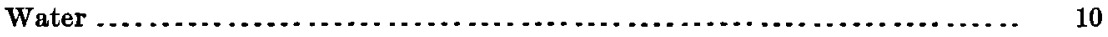

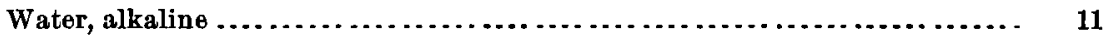

White, Dr. C. A., cited ...................................... 11

Wood, silicified ................................................ 11

(348) 
L. B. GROLOGICAL BURVEI.

BUtLETIN NO. 21 PL. I.

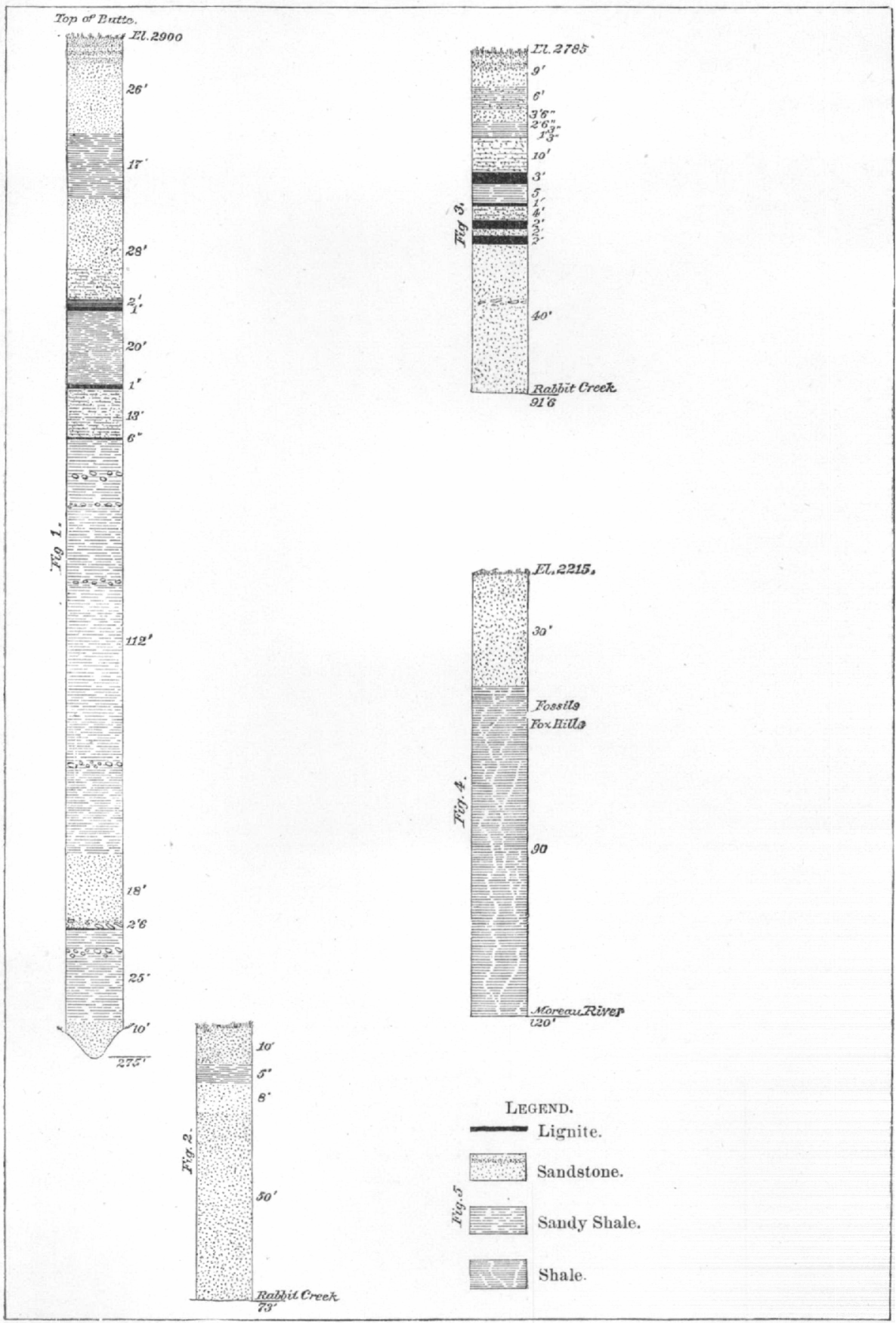

SECTIONS OF THE LARAMIE-RABBIT CREEK AND MOREAU RIVER, 



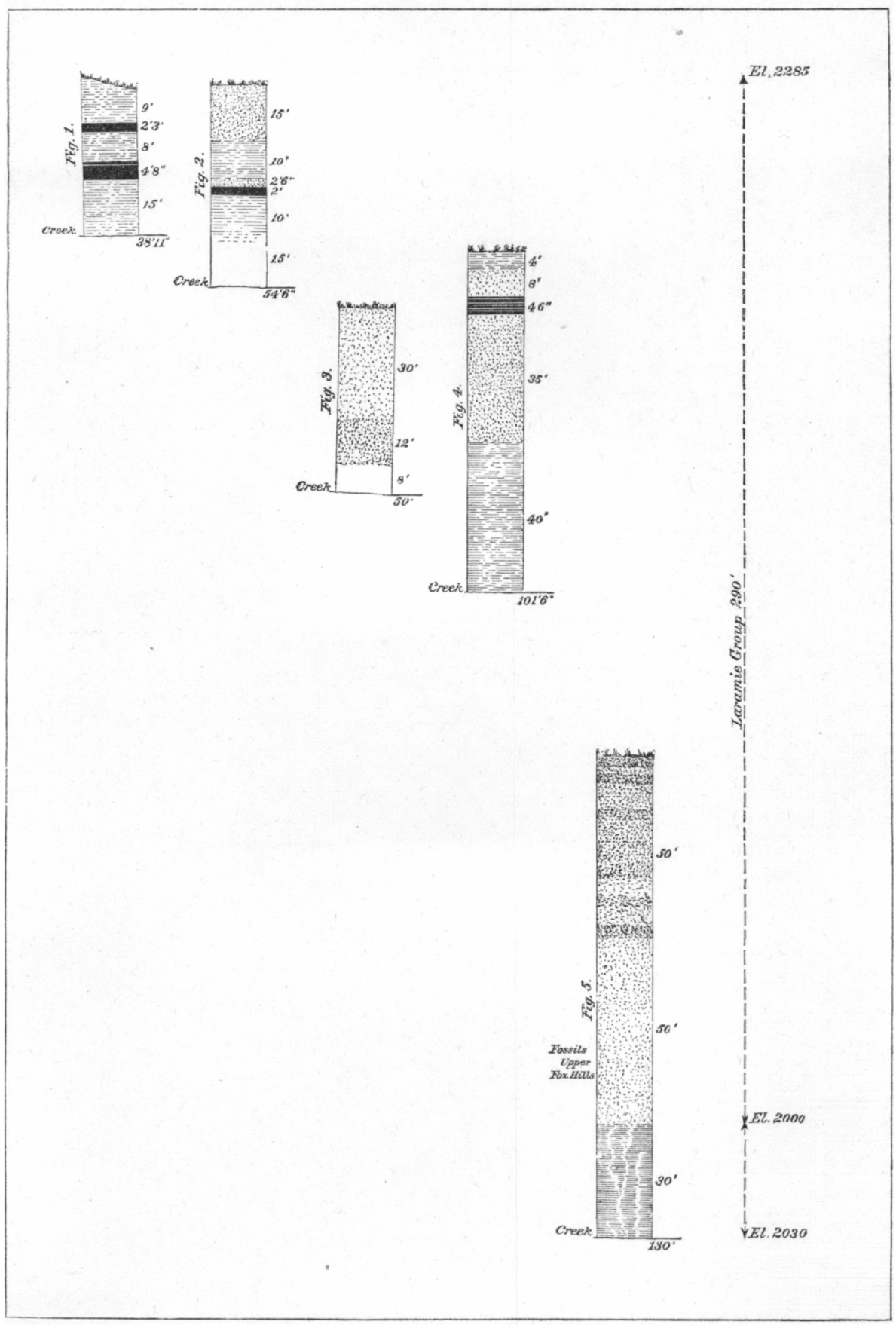

SECTIONS OF THE LARAMIE-FLINT CREEK. 


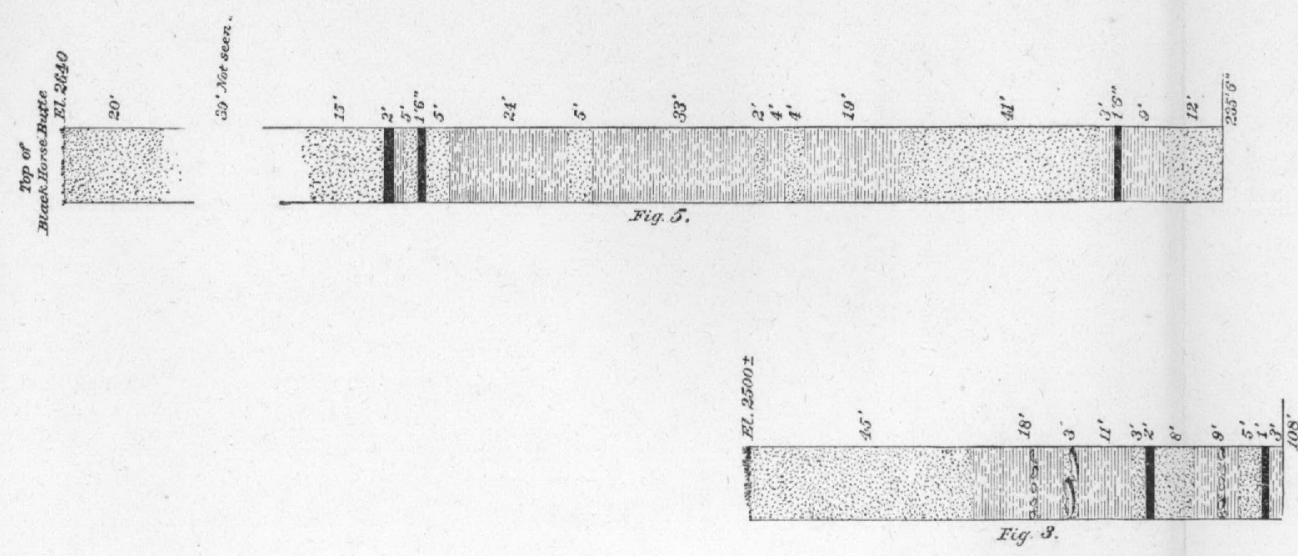

高

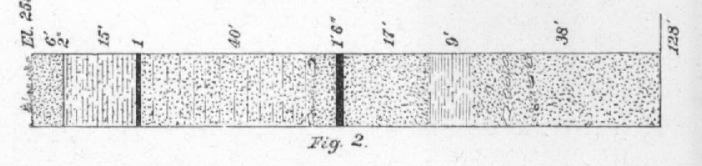

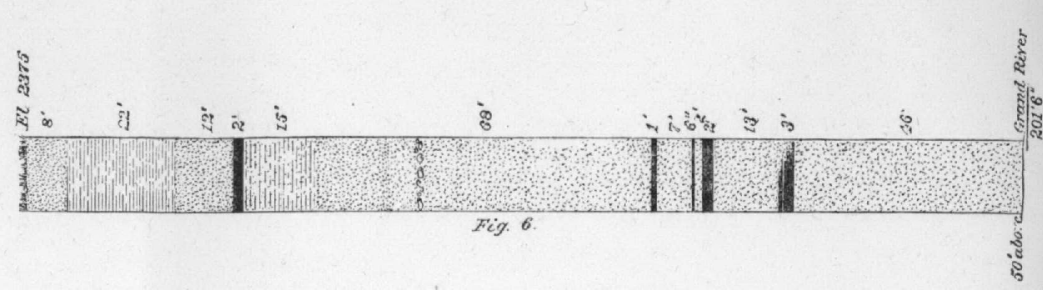

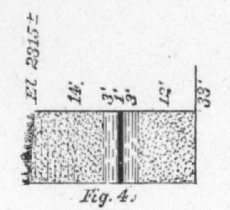

Hii 


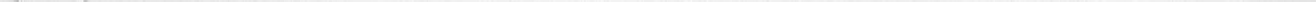




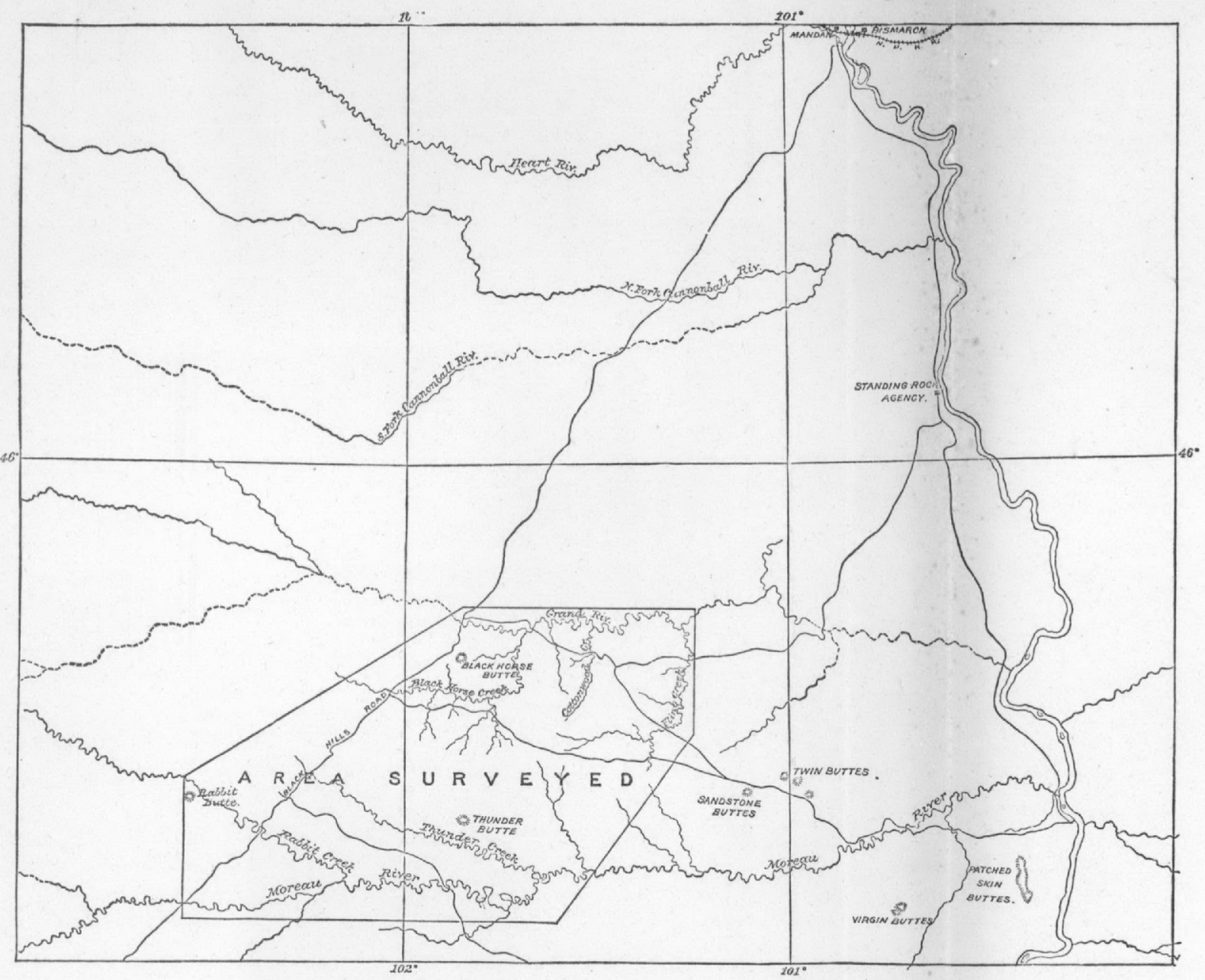

MAP OF PART OF DAKOTA, WEST OF THE MISSOCRI RIVER, SHOWING LOCALITY OF SPECIAL SURVEY IN THE GREAT SIOUX RESERVATION. 



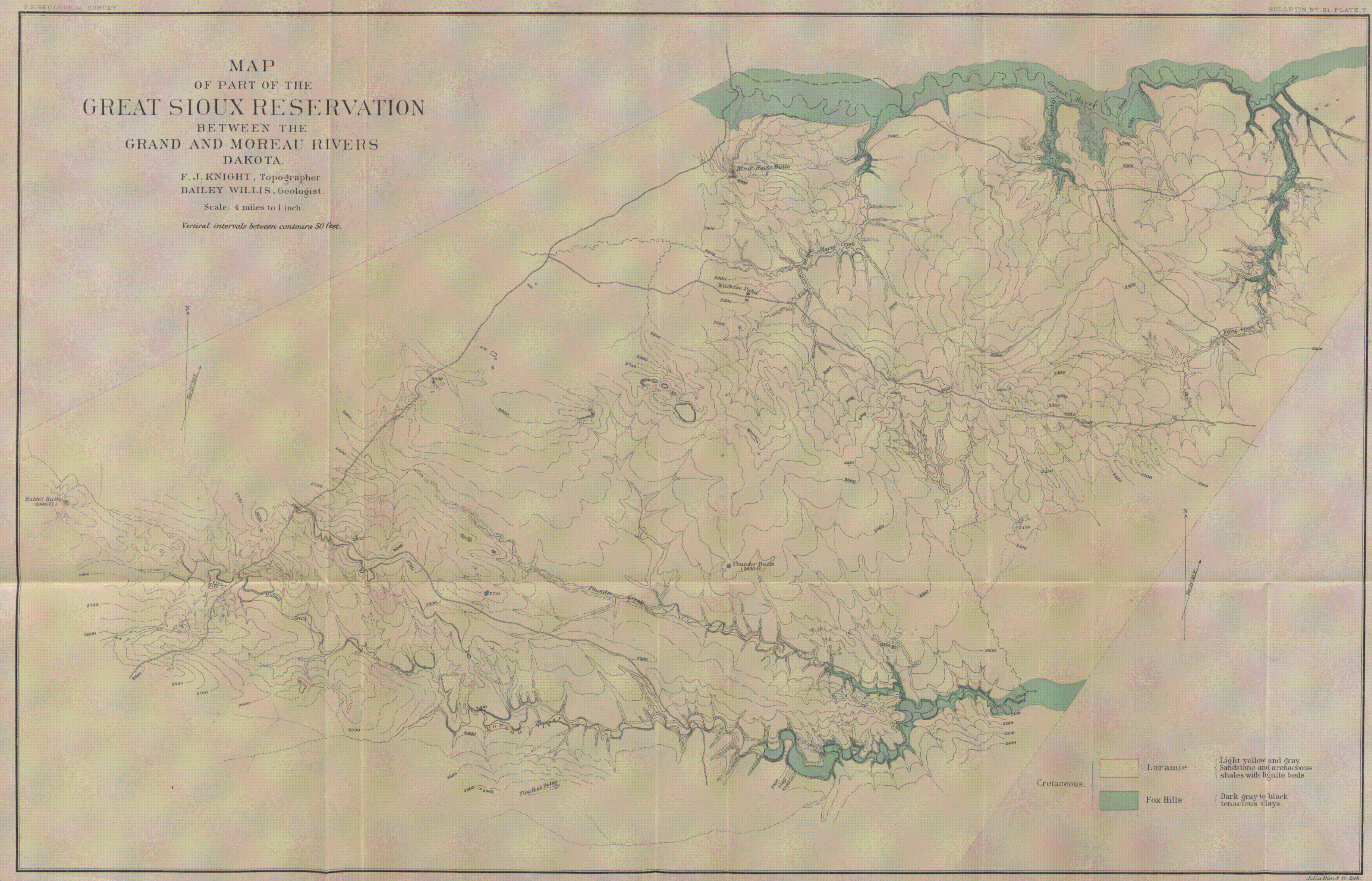


